\title{
Lactobacillus curvatus from fermented sausages as new probiotic functional foods
}

\author{
Tanja Žugić PETROVIĆl* (D), Predrag ILIĆ ${ }^{2}$, Mirjana GRUJOVIĆ ${ }^{1}$, Katarina MLADENOVIĆ ${ }^{1}$, \\ Sunčica KOCIĆ-TANACKOV ${ }^{3}$, Ljiljana ČOMIĆ ${ }^{1}$
}

\begin{abstract}
This research examined in vitro probiotic potential of Lactobacillus curvatus isolates from fermented sausage originating in Southeast Serbia which was prepared using traditional production techniques. Strains of L. curvatus were isolated and identified at the level of species using API 50CHL sets and 16s rDNA sequencing, after which their probiotic potential was measured. The research consisted of the examination of isolate survival rates in the gastrointestinal tract, synthesis of biogenic amines, the growth on the media with different quantities of phenol, antibiotic resistance test, and antimicrobial activity against clinical strains of Pseudomonas spp., Proteus spp., Enterobacter spp., Escherichia coli and Listeria monocytogenes. The examined isolates have shown a good survival rate at low $\mathrm{pH}$ in the simulated stomach and small intestine conditions. Synthesis of biogenic amines was exhibited by the isolate sk1-10, which had a positive reaction to histidine. Analyzed isolates grew well on media with $0.1 \%$ and $0.2 \%$ of phenol, L.curvatus sk1-8 and sk5-2 have grown in media with $0.3 \%$ phenol. All tested isolates have exhibited high sensitivity to most analyzed antibiotics (tetracycline, amoxicillin, ceftriaxone, erythromycin, penicillin), resistance to ofloxacin, and cephalexin isolates sk4-3a and sk4-15. The examined isolates have shown a broad inhibitory spectrum against pathogens.
\end{abstract}

Keywords: probiotic characteristics; spontaneously fermented sausages.

Practical Application: Use of Lactobacillus curvatus isolates as additives in fermented sausages.

\section{Introduction}

Due to their sustainability and high quality compared to most other meat products, fermented sausages represent the food most consumers in this area gladly choose. Modified living conditions and diet, which is significantly influenced by technology development, led to the improvement and increase in volume and expansion of the selection of fermented sausages. Today special attention is paid to manufactured (homemade) spontaneously fermented sausages defined as a dry-cured or dried mixture of different meats with the addition of salt, sugar, and spices (Žugić Petrović et al., 2019).The sustainability of spontaneously fermented sausages is based on biochemical and physicochemical changes during fermentation and curing; that is, the microbiota that develops in fermented sausages is the essential factor in defining the quality and maturity of sausages. (Adıgüzel \& Atasever, 2009). An autochthonous microbiota is developed by natural contamination during slaughtering in traditional sausages and increases production (Semedo-Lemsaddek et al., 2016). As a consequence, there is a large number of isolated and identified wild strains whose technological properties, first of all, good proteolysis, lipolysis, decarboxylation of specific amino acids, the production of antimicrobial compounds make them desirable for the meat industry (Messens et al., 2003; Mauriello et al., 2004). Spontaneously fermented sausages are continuously used as a source of wild strains, primarily of Lactic acid bacteria (LAB) and strains from the family of Micrococcaceae. Lactic acid bacteria have a significant role in this as they affect the technological properties and microbial stability of the final product through the production of milk and acetic acid, the synthesis of which reduces the $\mathrm{pH}$ of the product resulting in the inhibition of the growth of pathogenic microorganisms (Drosinos et al., 2007). In Southeast Europe, the production of spontaneously fermented sausages is widespread and is characterized by variations in the raw material composition, formulation, and production process. Their microbiota is characterized by the dominance of Lactobacillus sakei, Lactobacillus curvatus, Lactobacillus plantarum, Leuconostoc sp. and Weissella sp. (Parente et al., 2001; Drosinos et al., 2005; Comi et al., 2005; Rantsiou \& Cocolin, 2006; Urso et al., 2006). Several studies have suggested that the wild strains of LAB, in addition to technological characteristics, also have good probiotic properties, which makes them essential to the meat industry as starters for the production of fermented sausages (Papamanoli et al., 2003; DeVuyst et al., 2008; Yuksekdag \& Aslim, 2010). The definition of the strain as a potential probiotic is complex. The strain must be thoroughly tested and fulfill all the necessary conditions for attaining FDA status "GRAS," generally recognized as safe for human use. Probiotics are a group of live microorganisms that exert favorable effects on humans and animals, primarily by balancing the intestinal flora when administered in adequate amounts (Zendeboodi et al., 2020). Probiotic foods have beneficial effects on the G.I. tract, improve the functioning of intestinal barriers and reduce lactose intolerance, influence the secretion and appetite, relieve food 
allergies, help the immune system andlower blood pressure, and prevent osteoporosis (Hansson et al., 2020; Lee et al., 2020; Eor et al., 2020).

The advantage of using $\mathrm{LAB}$ as probiotics for the meat industry is reflected in the fact that LAB originating from fermented meats are specially adapted to the ecology of meat fermentation (Hugas \& Monfort, 1997). Adding probiotics as starter cultures to fermented sausages increases the health benefits of lactic acid bacteria and contributes to increasing the consumption of fermented meat products (DeVuyst et al., 2008). Numerous authors have emphasized the importance of healthy meat and meat products by reducing harmful ingredients and adding thosefavorable to human health (Paglarini et al., 2020; Vidal et al., 2020). This paper aims to examine the probiotic potential of LAB isolated from fermented sausages from Southeast Serbia (Sokobanja) and characterize isolated L. curvatus from naturally spontaneously fermented dry sausages traditionally produced in households to be used as starter cultures.

\section{Materials and methods}

\subsection{Sausage -making and sampling}

Spontaneously fermented sausage is an autochthonous product from Southeast Serbia traditionally produced in the winter months from November to February. It consists of cold pig meat, first and second category, bacon, around $2 \%$ of kitchen salt, hot and mild red peppers, approximately $1 \%$ of garlic, $0.05 \%$ of black and white pepper, $0.02 \%$ of sugar (the ratio of the ingredients is following the traditional recipe of the manufacturer itself). The sausage is cured on cold beech smoke for about 25 days and then dried in the air. The product stays in the open air until low air temperatures permit the preservation. Spontaneous fermentation of this sausage leads to the development of the characteristic microbiota and sensory characteristics of this product, by which it is known.

\subsection{Isolation and phenotypic characterizationof lactic acid bacteria}

The researchincluded LAB isolates from 10 samples of fermented sausage. The sausage cover was removed aseptically. Then, $25 \mathrm{~g}$ samples were taken and homogenized with $225 \mathrm{~mL}$ of physiological saline water $(0.85 \mathrm{NaCl} \%$, Hemofarm, Vršac, Serbia) in a vortex (Nasco Whirl-pack; USA) for 1 min. Further delusions were prepared using the method above. Isolation and identification of LAB was made on De Man Ragosa Sharpe Agar (Torlak, Beograd, Serbia) (meat peptone $10 \mathrm{~g}$, meat extract $10 \mathrm{~g}, \mathrm{~K}_{2} \mathrm{HPO}_{4} 2 \mathrm{~g}, \mathrm{MnSO}_{4} \mathrm{xH}_{2} \mathrm{O} 0,05 \mathrm{~g}, \mathrm{MnSO}_{4} \mathrm{x} 7 \mathrm{H}_{2} \mathrm{O} 0,2 \mathrm{~g}$, ammonium citrate $2 \mathrm{~g}$, yeast extract $5 \mathrm{~g}$, glucose $20 \mathrm{~g}$, agar $15 \mathrm{~g}$, distilled water to $1000 \mathrm{~mL}$ ) plates for $48-72$ hours at $30^{\circ} \mathrm{C}$. Twenty colonies were randomly selected from each MRSA plate and transferred to new agar plates for purification. The morphology of all isolates was determined using a microscope. Gram-positive, catalase-negative, non-spore-forming isolates were regarded as LAB. After isolation, a series of biochemical tests were carried out that included:

Arginine hydrolysis was analyzed by growing the culture in arginine broth (HiMedia Laboratories, Mumbai, India). After incubation, a few drops of phenol red were added to arginine broth (occurrence of red color indicates a positive reaction, and yellow negative) (Phalakornkule \& Tanasupawat, 2007).

The ability to grow on MRS agar at different temperatures $\left(15^{\circ} \mathrm{C}\right.$ and $\left.45^{\circ} \mathrm{C}\right)$ was measured using the method described by Kloos et al. (1974), with certain modifications.

Growth ability on MRS agar in the presence of 4 and $6.5 \%$ $\mathrm{NaCl}$ was examined using the method described by Phalakornkule \& Tanasupawat (2007).

$\mathrm{CO}_{2}$ production from glucose was examined using MRS broth with Durham tubes (Phalakornkule \& Tanasupawat, 2007).

Lipolytic activity was assessed according to the method described by Harrigan \& McCance (1976). Some modifications on the medium were made by adding egg yolk (4\%) to the nutrient agar.

Proteolytic activity was examined according to the method described by Harrigan \& McCance (1976) with certain modifications.

Exopolysaccharide synthesis was detected visually using the method described by Drosinos et al. (2005) (appearance of gelatinous colonies) after incubation of isolates on modified nutrient agar with (10\%) of sucrose, fructose, lactose, and glucose (Torlak, Belgrade, Serbia) at a temperature of $30^{\circ} \mathrm{C} / 48 \mathrm{~h}$.

$\mathrm{LAB}$ isolates were further identified using API $50 \mathrm{CH}$ tests, a bacterial identification system (BioMerieux, S.A., France).

\subsection{Identified by 16s rDNAsequencing}

DNA extraction from pure cultures, PCR amplification with (GTG)5-primer, and electrophoresis were done in accordance with Nikolic et al. (2008). In order to sequence the 16S rRNA gene, total DNA was used for PCR amplification with primers UNI16SF (5'-GAG AGT TTG ATC CTG GC-3) and UNI16SR (5'-AGG AGG TGA TCC AGC CG-3'). To amplify the variable region of the $16 \mathrm{~S}$ rRNATaq DNA polymerase kit (Fermentas UAB, Vilnius, Lithuania) was used. PCR reactions were carried out in GeneAmp PCR System 2700 (Applied Biosystems), which was programmed in the following manner: initial DNA denaturation at $94{ }^{\circ} \mathrm{C}$ for $5 \mathrm{~min}$, followed by $94{ }^{\circ} \mathrm{C}$ for $30 \mathrm{~s}, 55^{\circ} \mathrm{C}$ for $30 \mathrm{~s}$ and $72{ }^{\circ} \mathrm{C}$ for $30 \mathrm{~s}$ for 30 cycles and final extension at $72{ }^{\circ} \mathrm{C}$ for $7 \mathrm{~min}$. PCR samples were quantified by electrophoresis on a $1 \%$ agarose gel containing etethidium bromide and visualized by the CCD camera Biometra BDR2/5/6 (Bio Doc Analyze). These fragments were then purified by QIAquick PCR Purification Kit/250 (QIAGEN GmbH, Hilden, Germany) and sequenced at Macrogen in Seoul, South Korea. The BLAST algorithm (http://www.ncbi.nlm.nih.gov/BLAST) was used to determine the most related sequencerelatives in the NCBI nucleotide sequence database.

\subsection{Probiotic tests in vitro}

\section{Survival in the gastrointestinal tract}

The test of survival capacity in the G.I. tract included growth at low $\mathrm{pH}$ values, gastro test, and the bile salt tolerance. 
Growth at low $\mathrm{pH}$ values was determined by the inoculation of an overnight culture of microorganisms in MRS broth (Torlak, Belgrade, Serbia) with $\mathrm{pH}$ values 3.0, 4.0, and 5.0 (adjusted with $0.1 \mathrm{M} \mathrm{HCl}$ ). $\mathrm{pH}$ value 5.0 was used as a control. Tubes were incubated $48 \mathrm{~h}$ at the temperature of $37^{\circ} \mathrm{C}$.

Gastro test. Overnight cultures of isolates were inoculated in ratio $1: 10$ into the solution of $0.5 \% \mathrm{NaCl}$ and $0.22 \%$ pepsin with $\mathrm{pH}$-value 2.0 (adjustedby $1 \mathrm{M}$ of $\mathrm{HCl}$ ) and incubated at $37^{\circ} \mathrm{C}$ for $1 \mathrm{~h}$ and $2 \mathrm{~h}$. After the incubation, the number of LAB was determined by transferring the appropriate dilutions onto the MRS agar plates (Radulović et al., 2010).

Bile salt tolerance. Overnight cultures of isolates were inoculated into a solution of $0.2 \%$ pancreatin, $0.4 \%$ of bile salts, and $0.5 \%$ of $\mathrm{NaCl}$ with $\mathrm{pH}$-value 8 utilizing $1 \mathrm{M} \mathrm{NaOH}$ solution. Tubes were incubated for $4 \mathrm{~h}$ and $6 \mathrm{~h}$ at the temperature of $37^{\circ} \mathrm{C}$. After the incubation, the number of LAB was determined by transferring the appropriate dilutions onto the MRS agar plates (Radulović et al., 2010). The experiment has been done in three repeats.

\section{Synthesis of biogenic amines}

Isolates' ability to synthesize biogenic amines from histidine and tyrosine has been performed using the method described by Maijala \& Eerola (1993). The purple color of the colonies on the plates with histidine or the appearance of sediment around the colonies on the plateswith tyrosine confirms the ability of the strain to produce biogenic amines.

\section{Growth on medium with different quantity of phenol}

Growth capacity of isolates in the presence of phenol was conducted by inoculatingovernight isolate cultures onto the MRS agar plates and adding $0.1 \%, 0.2 \%$, and $0.3 \%$ of phenol. The existence of colonies after $48 \mathrm{~h}$ of incubation at $37^{\circ} \mathrm{C}$ indicates the isolates' survivalrate in the presence of specificphenol concentrations (Šušković et al., 2000).

\section{Resistance of isolates to antibiotics (disc-diffusion test)}

Resistanceof isolated strains to antibiotics has been examined using the disc diffusion method, with BBL (Baltimore Biological Laboratory) discs impregnated by tetracycline $30 \mu \mathrm{g} / \mathrm{mL}$, cefalexin $30 \mu \mathrm{g} / \mathrm{mL}$, amoxicillin $20 / 10 \mu \mathrm{g} / \mathrm{mL}$, ceftriaxone $30 \mu \mathrm{g} / \mathrm{mL}$, erythromycin $15 \mu \mathrm{g} / \mathrm{mL}$, penicillin $10 \mathrm{U}$ and ofloxacin $5 \mu \mathrm{g} / \mathrm{mL}$ (BBL Sensi-Disc Antimicrobial Susceptibility Test Discs, Becton, Dickinson\&Company). Several identical colonies of LAB strains were re-suspended at $5 \mathrm{~mL}$ of physiological solution, and the standardization of suspension was achieved by comparison withMcFarland standard No 1 . The strains were swabbed on the surface of the MRS agar plates, and the BBL disks impregnated with antibiotics were applied on the surface (Ledina et al., 2013). After applying the suspension of cultures onto a plate surface, BBL discs were applied by sterile tweezers. Plates were incubated for $24 \mathrm{~h}$ at $37^{\circ} \mathrm{C}$. After the incubation, inhibition zones of examined strains were measured. LAB strains that show inhibition zones larger than $21 \mathrm{~mm}$ were considered susceptible, and those with zones smaller than $15 \mathrm{~mm}$ were deemed resistant. The isolates showing inhibition zones from 15 to $21 \mathrm{~mm}$ were considered moderately susceptible (Vlková et al., 2006).

\section{Antimicrobial activity}

Antimicrobial activity has been tested usingthe modified method of Vesković Moračanin et al. (2009). Petri dishes were overlaid by $10 \mathrm{~mL}$ of soft nutrition agar (1\% agar) (Torlak, Belgrade, Serbia) inoculated with the overnight culture of indicator strain to obtain $10^{5}-10^{6} \mathrm{CFU} / \mathrm{mL}$ of medium, then wells of $5 \mathrm{~mm}$ diameter were formed in the agar and $100 \mu \mathrm{L}$ of partially purified bacteriocin was pured into the wells. Partial purification of bacteriocins was done using the following method. After $18 \mathrm{~h}$ of growth on MRS broth (Torlak, Belgrade, Serbia), the cultures were centrifugated at $10000 \mathrm{rpm}$ for around 30 minutes at the temperature of $4{ }^{\circ} \mathrm{C}$. After this, the preparation supernatant was neutralized to $\mathrm{pH}=6.5-7.0$ by $10 \mathrm{M} \mathrm{NaOH}$. Precipitation of bacteriocin was performed by ammonium sulfate $(472.2 \mathrm{~g} / \mathrm{L})$ until a saturated solution was obtained. Separated bacteriocin in the form of white residue was dissolved in $25 \mathrm{~mL} 0.05 \mathrm{M}$ of sodium phosphate buffer $\mathrm{pH} 7$. The partially purified bacteriocin was made by filtrating through a $0.22 \mu \mathrm{m}$ microfilter (Acrodisc, Germany). Antimicrobial activity was recorded as the appearance of a light zone around wells. . As indicator strains, clinical isolates were used: Pseudomonas spp. (isolated from wound), Proteus spp., Enterobacter spp., E. coli (isolated recovered from sputum) and L. monocitogens (isolated from stomach contents). All the isolates were obtained from the laboratory of the Special hospital for lung diseases Ozren, Sokobanja. Microbiological examinations of clinical samples in the laboratory of the Special hospital Ozren are done per international standard for medical laboratories SRPS ISO 15189:2008.

\section{Results and discussion}

\subsection{Phenotypic characterization of LAB}

From the ten dry sausages as sayed, 209 strains were isolated (data not shown). The nine candidate probiotic strains were preliminarily characterized and grouped with biochemical API tests (Table 1). Homofermentary rods had a negative reaction to arginine, did not possess lipolytic and proteolytic abilities, grew well at a temperature of $15^{\circ} \mathrm{C}$ in mediums with $6.5 \% \mathrm{NaCl}$, had a positive fermentation reaction to sucrose and cellobiose. They did not ferment esculin, mannitol, melezitose, raffinose, sorbitol, xylose, gluconate and melibiose. According to the pattern of sugar fermentation, these isolates were identified as L.curvatus.

Preliminarily identified $L$. curvatus isolates were subsequently differentiated and characterized at the species level. The use of (GTG) 5-PCR fingerprinting, and 16S rDNA sequencing confirmed the preliminary identification of L. curvatus. Many authors confirm the presence of $L$. curvatus in fermented sausages, and its adaptability can explain the presence of this homofermentative bacillus to the environmental conditions during the production of fermented sausages, as well as lower $\mathrm{pH}$ values and high concentrations of $\mathrm{NaCl}$ in the product. $\mathrm{Di}$ Cagno et al. (2008) identified that the presence of L. curvatus in the Italian "varza" sausage ranges up to $80 \%$ of the total 
Table 1. Results of tests characterization of L.curvatus.

\begin{tabular}{|c|c|c|c|c|c|c|c|c|c|}
\hline Isolate marking & sk1-8 & sk1-10 & sk2-17 & sk3-18 & sk4-3a & sk4-15 & sk5-2 & sk6-5 & sk6-12 \\
\hline \multicolumn{10}{|l|}{ Growth at: } \\
\hline \multicolumn{10}{|l|}{$15^{\circ} \mathrm{C}$} \\
\hline $45^{\circ} \mathrm{C}$ & + & + & + & + & + & + & + & + & + \\
\hline \multicolumn{10}{|l|}{ Growth in: } \\
\hline \multicolumn{10}{|l|}{$4.0 \% \mathrm{NaCl}$} \\
\hline \multicolumn{10}{|l|}{ Growth in: } \\
\hline pH 3 & + & + & + & + & + & + & + & + & + \\
\hline $\mathrm{pH} 4$ & + & + & + & + & + & + & + & + & + \\
\hline pH 5 & + & + & + & + & + & + & + & + & + \\
\hline Gas from glucose & - & - & - & - & - & - & - & - & - \\
\hline \multicolumn{10}{|c|}{ Biochemical (API) tests } \\
\hline $\mathrm{L}$-arabinose & - & - & - & - & - & - & - & - & - \\
\hline Cellobiose & + & + & + & + & + & + & + & + & + \\
\hline Ribose & + & + & + & + & + & + & + & + & + \\
\hline Esculin & + & + & + & + & + & + & + & + & + \\
\hline Galactose & + & + & + & + & + & + & + & + & + \\
\hline Lactose & + & + & + & + & + & + & + & + & + \\
\hline D-mannose & + & + & + & + & + & + & + & + & + \\
\hline Melezitose & - & - & - & - & - & - & - & - & - \\
\hline Melibiose & - & - & - & - & - & - & - & - & - \\
\hline Sorbitol & - & - & - & - & - & - & - & - & - \\
\hline Salicin & + & + & + & + & + & + & + & + & + \\
\hline \multicolumn{10}{|l|}{$\begin{array}{l}\text { Concentration of } \\
\text { phenol }\end{array}$} \\
\hline \multicolumn{10}{|l|}{$0.1 \%$} \\
\hline $0.2 \%$ & + & + & + & + & + & + & + & + & + \\
\hline \multirow[t]{2}{*}{$0.3 \%$} & + & + & + & + & + & + & + & + & + \\
\hline & + & - & - & - & - & - & + & - & - \\
\hline \multicolumn{10}{|l|}{ Amino acids } \\
\hline histidine & - & + & - & - & - & - & - & - & - \\
\hline tyrosine & - & - & - & - & - & - & - & - & - \\
\hline
\end{tabular}

Identificationby 16s RNA sequencingL.curvatus. (+) positive; (-) negative.

microbiota of the product. Aquilanti et al. (2016) emphasize the dominance of Lactobacillus sakei and L. curvatus strains in traditional fermented sausages from the Mediterranean. Studija Fontán et al. (2007) described L. curvatus as the third bacterial species of quantitative importance in Spanish traditional pork sausage "Botillo."Vasilev et al. (2015), in their paper on the fermented sausage "Lemeški kulen," reported that L. curvatus presented $15.8 \%$ of the total microbiota of the product.

\subsection{In vitro tests related to probiotic potential}

\section{Survival in the gastrointestinal tract}

One of the conditions that manifest probiotic characteristics is survival of the strains through the gastrointestinal tract (G.I.) that possesses very harsh conditions for the survival of microorganisms. G.I. tract is characterized by low $\mathrm{pH}$-values, the range of which is from 1.5 to 3.0 (Shin et al., 2008). The results 
of study ingthe survival of LAB strains in the conditions of the G.I. tract have shown a high level of acid tolerance. Growth was observed with all the examined isolates of lactobacilli (9 isolates) that have grown at $\mathrm{pH}$ 3.0,4.0, and 5.0. Brink et al. (2006) emphasize that the growth of $\mathrm{pH} 3.0$ of five LAB strains was suppressed in the first 10 hours of incubation, while the development of the tested strains was much more energetic between $\mathrm{pH} 5.0$ and 6.5 .

\section{Gastro test}

By analyzing the isolates'survival ability in the stomach conditions, it has been noticed that the number of lactobacilli cells after the first hour of incubation did not decrease for all examined strains. The number of cells for three analyzed strains was maintained on the same level (isolates sk1-10, sk2-17, and sk4-15 in Figure 1). Two strains (sk4-3a and sk6-12) showed a slight increase after one $h$ of incubation. The isolate of L.curvatus sk6-12 maintained the same number of cells after the second hour of incubation. The average survival of the L.curvatus isolates after two $\mathrm{h}$ of incubation in the medium simulating stomach conditions was $84 \%$. It canbe concluded that analyzed strains of $L$. curvatus showed a high level of survival in simulated conditions of the stomach, which is in accordance with the results Ledina et al. (2013) reported that the survival of lactobacilli cells in simulated conditions of the stomach during the first hour was $96.22 \%$. Bacha et al. (2009), in their work on probiotic characteristics of lactobacilli isolated from the beef sausage, also showed a high degree of survival of examined strains in simulated stomach conditions. The interaction with present microbiota in the specific food matrixes is also important, according to Sieladie et al. (2011). Lactobacilli in meat and fat matrix in vivo have a higher degree of survival during transit through the stomach and intestines (Erkkilä \& Petäjä, 2000). Food components can increase the protection of probiotic cultures themselves and thereby increase their activity and life.

\section{Bile salts tolerance}

Since all the strains of lactobacilli have shown a high level of acido-tolerance, they have been subjected to further study of survival in small intestine conditions. There is no consensus on the concentration of bile salts onto which the chosen strain should be tolerant (Klayraung et al., 2008). The concentration of bile salts in the small intestine goes within limits of $0.1-0.5 \%$ (Mathara et al., 2008). The maximum concentration was noticed in the first hour of digestion, so the ability of strains to survive the concentration of $0.4 \%$ in accordance with available literature data on the digestive system of people (Ledina et al., 2013). The survival of the strains was monitored after 4and $6 \mathrm{~h}$ of incubation. The reduction in the number was observed for four isolates (sk1-8, sk1-10, sk2-17, and sk3-18 in Figure 2), while in 3 strains (sk4-3a, sk5-2, and sk6-5), the increase of the number after four $\mathrm{h}$ was noticed. After 6 hours of incubation, the number was maintained on the same level or reduced. One isolate (sk6-12) retains the number of cells after four $h$, where by it decreases after six $h$ of incubation in simulated conditions of the small intestine. Hawaz (2014), in their paper on probiotic characteristics of LAB, showed that the number of lactobacilli in simulated conditions

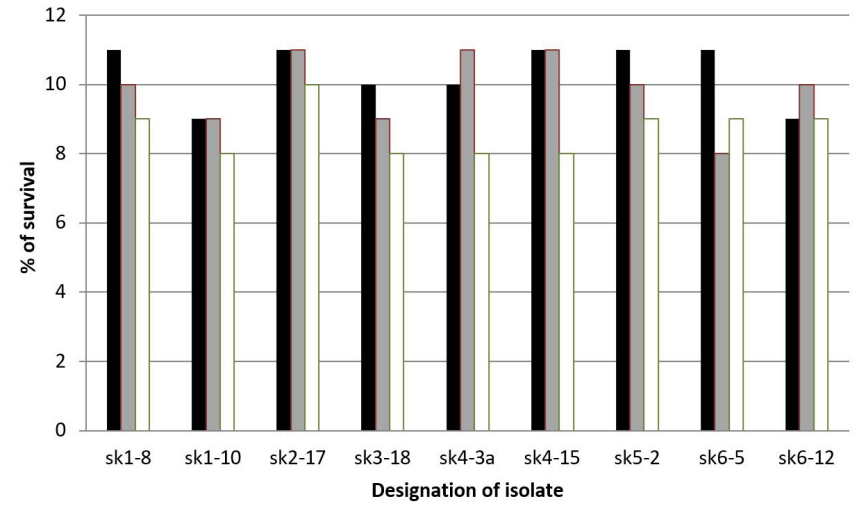

Figure 1. Lactobacilli survival during the incubation in simulated conditions of stomach environment (Initial number-black bars, one $\mathrm{h}$ of incubation -gray bars, two h of incubation - white bars).

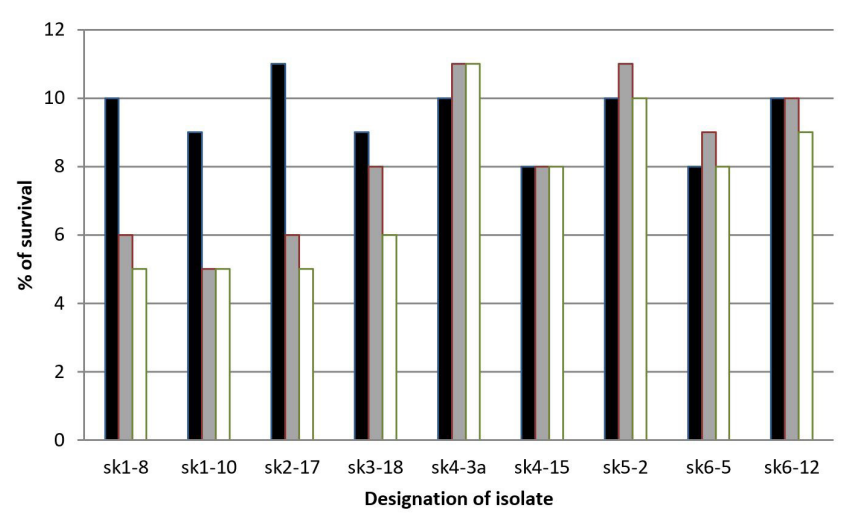

Figure 2. Lactobacilli survival during the incubation in simulated conditions of intestinal tract (Initial number-black bars, $4 \mathrm{~h}$ of incubation -gray bars, $6 \mathrm{~h}$ of incubation - white bars).

of the small intestine decreased insignificantly after four $\mathrm{h}$, and that reduction was within the boundaries of $0.3 \%$. The paper by Klayraung et al. (2008) showed that $60 \%$ of examined strains of Lactobacillus fermentum can survive the concentration of bile salts within the range of 0.3 and $0.5 \%$, while the number of viable cells gradually decreases by increasing the concentration of bile salts up to $1.0 \%$. The resistance of lactobacilli to the toxicity of conjugated bile salts in the conditions of intestinal tract environment represents an important factor of colonization and survival of lactobacilli population in this environment (De Smet et al., 1995).

\subsection{Tests of synthesis of biogenic amines}

Biogenic amines are organic bases and may occur in the process of fermentation of meat and meat products. On the other side, they may occur as a product of the enzyme activity of microorganisms. In fermented meat products synthesis of biogenic amines by individual microorganisms is higher due to high contents of protein and highproteolytic activity duringthe long-lasting ripening of these products (Macedo et al., 2012). Biogenic amines are considered undesirable metabolic products 
of potential probiotic strains. The microorganism with the ability to produce them cannot be used as a starter culture and even less as a probiotic (Ammor \& Mayo, 2007). The highest number of research on dairy and meat product starters was done with amino acid tyrosine and histidine (Belicová et al., 2013; Työppönen et al., 2003; Bacha et al., 2009). The investigated isolates of L.curvatus do not exhibit the ability to synthesize biogenic amines on mediums with tyrosine and histidine, except for sk1-10 that had a positive reaction to histidine (Table 1). Tomé et al. (2008), in their work, point out that L. curvatus ET30 did decarboxylate tyrosine to form tyramine.

\subsection{Growth on media with phenol}

Phenol in the body occurs by bacterial deamination of aromatic amino acids formed by hydrolysis of proteins from food or produced endogenously (Suskovic et al., 1997). The amount of phenol that occurs in the colon varies and has a very negative impact on human health, while some studies have shown that it affects the incidence of colon cancer (Nowak et al., 2014). In the process of digestion, it is vital to reduce the transit time through the colon and thus reduce the disorders that can occur (Nowak et al., 2014). Heterocyclic aromatic amines (HCAs) introduced into heat-treated meat can contribute to the development of colon cancer. Probiotic lactobacilli bind to HCA and remove carcinogens from the human body by reducing food transit.

Phenol has significant antimicrobial activity, so phenol-resistant bacteria are more likely to survive G.I. tract conditions (Žugić Petrović et al., 2020). Physiological levels of phenol in humans in intestinal contents are low; therefore, it is important to analyze the sensitivity of potential probiotics to this substance in concentrations in which phenols can be expected in the human body, in the range of $0.1 \%, 0.2 \%$, and $0.3 \%$. Examined L. curvatus showed growth inmedia with phenol in the concentration of $0.1 \%$ and $0.2 \%$, and L.curvatus sk $1-8$ and sk5-2 have grown in media with $0.3 \%$ phenol (Table 1.). The results obtained by Shinoda et al. (2000) indicate that none of the examined lactobacilli had growth in the concentration of phenol of cca $0.4 \%$, and that four of six Lactobacillus plantarum strains tolerated this concentration of phenol and that their number was not reduced concerning the value of initial inoculums.

\subsection{Antibiotic resistance}

Lactobacilli isolated from the spontaneously fermented sausage as potential probiotics have shown significant sensitivity on the test with commercial antibiotics, tetracycline $30 \mu \mathrm{g} / \mathrm{mL}$, cefalexin $30 \mu \mathrm{g} / \mathrm{mL}$, amoxicillin $20 / 10 \mu \mathrm{g} / \mathrm{mL}$, ceftriaxone $30 \mu \mathrm{g} / \mathrm{mL}$, erythromycin $15 \mu \mathrm{g} / \mathrm{mL}$, penicillin $10 \mathrm{U}$ and ofloxacin five $\mu \mathrm{g} / \mathrm{mL}$ (Table 2). Full resistance to antibiotics has not been shown by any examined isolate. Sensitivity to all antibiotics was demonstrated by the isolates of lactobacilli sk2-17, sk3-18, sk5-2,sk6-5, and sk6-12, and $22.2 \%$ have shown resistance to cefalexin and ofloxacin and $11.1 \%$ resistance to tetracycline and erythromycin. All isolates were sensitive to penicillin. Antibiotic resistance can be defined as natural and acquired resistance, and the mechanisms of the resistance are various (Courvalin, 2005). The use of antibiotic-resistant LAB strains in human and animal nutrition is a health threat since they might be able to transfer their resistant genes to pathogens (Hummel et al., 2007) and in such a way make the food unsafe.Lactobacilli are sensitive to antibiotics that inhibit protein synthesis (chloramphenicol, erythromycin, clindamycin, and tetracycline) and far more resistant to aminoglycosides (neomycin, kanamycin, streptomycin, and gentamicin) (Coppola et al., 2005). These microorganisms show high resistance to penicillin and ampicillin and a member of cephalosporins belonging to the beta-lactam family.

\subsection{Antimicrobial activity}

Antimicrobial activity has a significant role in the selection of strains as potential probiotics. The ability to prevent the growth of pathogenic microorganisms by synthesis of the appropriate compounds such as organic acids, hydrogen peroxide, diacetyl or bacteriocin, is a desirable characteristic of LAB strains. Two strains of L. curvatus isolated from Italian salami produce two bacteriocins, sakacin $\mathrm{P}$ and sakacin $\mathrm{X}$, with activity against L. monocytogenes (Laranjoet al.,2019). The spectrum of antimicrobial activity of LAB depends on genetic-phenotypic traits of species, i.e., on the ability to produce antimicrobials in given conditions (Zdolec et al., 2013). Antimicrobial activity of lactobacilli was examined on clinical isolates of pathogenic Pseudomonas spp., Proteus spp., Enterobacter spp., E. coli, and L. monocytogenes (Table 3). Isolates L. curvatus sk2-17, sk3-18, sk4-15, and sk6-12 showed inhibition against all examined clinical

Table 2. The results of antibiotic resistance of $L$. curvatus strains.

\begin{tabular}{|c|c|c|c|c|c|c|c|}
\hline \multirow{2}{*}{ Lb. curvatus } & \multicolumn{7}{|c|}{ Antibiotics } \\
\hline & Tetracycline & Cefalexin & Amoxicillin & Ceftriaxone & Erythromycin & Penicillin & Ofloxacin \\
\hline sk1-8 & $\mathrm{S}$ & $\mathrm{S}$ & $\mathrm{S}$ & $\mathrm{S}$ & $\mathrm{S}$ & $\mathrm{S}$ & $\mathrm{R}$ \\
\hline sk1-10 & S & $\mathrm{R}$ & S & S & S & S & S \\
\hline sk2-17 & S & S & S & S & S & S & S \\
\hline sk3-18 & S & S & S & S & S & S & S \\
\hline sk4-3a & S & $\mathrm{R}$ & S & S & S & S & $\mathrm{R}$ \\
\hline sk6-5 & S & S & S & S & S & S & S \\
\hline sk6-12 & S & S & S & S & S & S & S \\
\hline
\end{tabular}

$\mathrm{R}=$ Resistant $\mathrm{S}=$ Susceptible 
Table 3. Inhibition zoneof L. curvatus against clinical isolates.

\begin{tabular}{|c|c|c|c|c|c|}
\hline \multirow{2}{*}{ Mark of strain } & \multicolumn{5}{|c|}{ Inhibition zone width, $\mathrm{mm}$} \\
\hline & Pseudomonas & Proteus & Enterobacter & L.monocytogenes & E.coli \\
\hline sk1-8 & 30 & 20 & $\mathrm{n} . \mathrm{z}$ & 18.5 & 20 \\
\hline sk1-10 & 35 & $\mathrm{n} . \mathrm{z}$ & 18.5 & 15 & 30 \\
\hline sk2-17 & 35 & 16 & 25 & 20 & 30 \\
\hline sk3-18 & 30 & 25 & 20 & 20 & 30 \\
\hline sk4-3a & 30 & 20 & n.z & 15 & $\mathrm{n} . \mathrm{z}$ \\
\hline sk4-15 & 30 & 30 & 18 & 22 & 18.5 \\
\hline sk5-2 & n.z & 25 & n.z & 16 & $\mathrm{n} . \mathrm{z}$ \\
\hline sk6-5 & n.z & n.z & 25 & 30 & 22 \\
\hline sk6-12 & 35 & 20 & 20 & 35 & 20 \\
\hline
\end{tabular}

$\mathrm{n} . \mathrm{z}=$ there is no inhibition zone.

isolates with the highest zone of inhibition against Pseudomonas, L. curvatus sk1-10 and sk4-3 had zones of inhibition of $15 \mathrm{~mm}$ to L.monocytogenes, and sk4-3a and sk5-2 did not show zones of inhibition against E. coli. Žugić Petrović et al. (2020), in their work on probiotic characteristics of LAB strains from dry-cured sheep ham, emphasize that all of the isolates showed the largest inhibition zone to $E$. coli ATCC 25922, where in the mean values of the inhibition zone ranged from 10.0 to $25.6 \mathrm{~mm}$.

\section{Conclusion}

The use of cultures with potential probiotic properties and antimicrobial activities in the production of fermented sausages provides significant health benefits and contributes to improving the hygienic quality of the product. The tested strains L. curvatus of spontaneously fermented sausages from Southeast Serbia possess favorable in vitro properties that make them potential candidates for probiotic applications. L. curvatus sk2-17, L. curvatus sk4-15, and L. curvatus sk5-2 showed the best potential probiotic properties like the ability to grow and survive from all the tested strains in the G.I. tract, the inability to synthesize biogenic amines, the presence of antibiotic sensitivity and good antimicrobial activity. These strains require further in vivo investigations to determine if they also function as probiotics in real-life situations.

\section{References}

Adıgüzel, G. C., \& Atasever, M. (2009). Phenotypic and genotypic characterization of lactic acid bacteria isolated from Turkish dry fermented sausage. Romanian Biotechnological Letters, 14(1), 4130-4138. Retrieved from https://www.rombio.eu/rbl1vol14/1-5/ lucr-7-Adiguzel-and-Atasever-bt.pdf

Ammor, M. S., \& Mayo, B. (2007). Selection criteria for lactic acid bacteria to be used as functional starter cultures in dry sausage production. An update. Meat Science, 76(1), 138-146. http://dx.doi. org/10.1016/j.meatsci.2006.10.022. PMid:22064200.

Aquilanti, L., Garofalo, C., Osimani, A., \& Clementi, F. (2016). Ecology of lactic acid bacteria and coagulase negative cocci in fermented dry sausages manufactured in Italy and other Mediterranean countries. International Food Research Journal, 23(2), 429-445. Retrieved from http://www.ifrj.upm.edu.my/23\%20(02)\%202016/(1).pdf

Bacha, K., Mehari, T., \& Ashenafi, M. (2009). In-vitro probiotic potential of lactic acid bacteria isolated from 'Wakalim' a traditional Ethiopian fermented beef sausage. Ethiopian Journal of Health Sciences, 19(1), 21-29. http://dx.doi.org/10.4314/ejbs.v6i2.45457.

Belicová, A., Mikulášová, M., \& Dušinský, R. (2013). Probiotic potential and safety properties of Lactobacillus plantarum from Slovak Bryndza Cheese. BioMed Research International, 2013, 760298. http://dx.doi. org/10.1155/2013/760298. PMid:24093103.

Brink, M., Todorov, S. D., Martin, J. H., Senekal, M., \& Dicks, L. M. (2006). The effect of prebiotics on production of antimicrobial compounds, resistance to growth at low $\mathrm{pH}$ and in the presence of bile, and adhesion of probiotic cells to intestinal mucus. Journal of Applied Microbiology, 100(4), 813-820. http://dx.doi.org/10.1111/ j.1365-2672.2006.02859.x. PMid:16553737.

Comi, G., Urso, R., Iacumin, L., Rantsiou, K., Cattaneo, P., Cantoni, C., \& Cocolin, L. (2005). Characterisation of naturally fermented sausages produced in the North East of Italy. Meat Science, 69(3), 381-392. http://dx.doi.org/10.1016/j.meatsci.2004.08.007. PMid:22062975.

Coppola, R., Succi, M., Tremonte, P., Reale, A., Salzano, G., \& Sorrentino, E. (2005). Antibiotic susceptibility of Lactobacillus rhamnosus strains isolated from Parmigiano Reggiano cheese. Le Lait, 85(3), 193-204. http://dx.doi.org/10.1051/lait:2005007.

Courvalin, P. (2005). Antimicrobial drug resistance. Prediction is very difficult, especially about the future. Emerging Infectious Diseases, 11(10), 1503-1506. http://dx.doi.org/10.3201/eid1110.051014. PMid:16318687.

De Smet, I., Van Hoorde, L., Vande Woestyne, M., Christiaens, H., \& Verstraete, W. (1995). Significance of bile salt hydrolytic activities of lactobacilli. The Journal of Applied Bacteriology, 79(3), 292-301. http://dx.doi.org/10.1111/j.1365-2672.1995.tb03140.x. PMid:7592123.

De Vuyst, L., Falony, G., \& Leroy, F. (2008). Probiotics in fermented sausages. Meat Science, 80(1), 75-78. http://dx.doi.org/10.1016/j. meatsci.2008.05.038. PMid:22063171.

Di Cagno, R., Chaves Lopez, C., Tofalo, R., Gallo, G., De Angelis, M., Paparella, A., Hammes, W., \& Gobbetti, M. (2008). Comparison of the compositional, microbiological, biochemical and volatile profile characteristics of three Italian PDO fermented sausages. Meat Science, 79(2), 224-235. http://dx.doi.org/10.1016/j.meatsci.2007.09.006. PMid:22062750.

Drosinos, E. H., Mataragas, M., Xiraphi, N., Moschonas, G., Gaitis, F., \& Metaxopoulos, J. (2005). Characterization of the microbial flora from a traditional Greek fermented sausage. Meat Science, 69(2), 307-317. http://dx.doi.org/10.1016/j.meatsci.2004.07.012. PMid:22062823.

Drosinos, H. E., Paramithiotis, S., Kolovos, G., Tsikouras, I., \& Metaxopoulos, I. (2007). Phenotypic and technological diversity 
of lactic acid bacteria and staphylococci isolated from traditionally fermented sausages in Southern Greece. Food Microbiology, 24(3), 260-270. http://dx.doi.org/10.1016/j.fm.2006.05.001. PMid:17188204.

Eor, J. Y., Tan, P. L., Son, Y. J., Lee, C. S., \& Kim, S. H. (2020). Milk products fermented by Lactobacillus strains modulate the gut-bone axis in an ovariectomised murine model. International Journal of Dairy Technology, 73(4), 743-756. http://dx.doi.org/10.1111/14710307.12708.

Erkkilä, S., \& Petäjä, E. (2000). Screening of commercial meat starter cultures at low $\mathrm{pH}$ and in the presence of bile salts for potential probiotic use. Meat Science, 55(3), 297-300. http://dx.doi.org/10.1016/ S0309-1740(99)00156-4. PMid:22061286.

Fontán, M. C. G., Lorenzo, J. M., Martínez, S., Franco, I., \& Carballo, J. (2007). Microbiological characteristics of Botillo, a Spanish traditional pork sausage. Lebensmittel-Wissenschaft + Technologie, 40(9), 16101622. http://dx.doi.org/10.1016/j.lwt.2006.10.007.

Hansson, P., Holven, K. B., Øyri, L. K. L., Brekke, H. K., Gjevestad, G. O., Rehfeld, J. F., Raza, G. S., Herzig, K. H., \& Ulven, S. M. (2020). Dairy products influence gut hormone secretion and appetite differently: a randomized controlled crossover trial. Journal of Dairy Science, 103(2), 1110-1119. http://dx.doi.org/10.3168/jds.201916863. PMid:31759587.

Harrigan, W. F., \& McCance, M. E. (1976). Laboratory methods in food and dairy microbiology (pp. 25-29). London: Academic Press.

Hawaz, E. (2014). Isolation and identification of probiotic lactic acid bacteria from curd and in vitro evaluation of its growth inhibition activities against pathogenic bacteria. African Journal of Microbiological Research, 8(13), 1419-1425. http://dx.doi.org/10.5897/AJMR2014.6639.

Hugas, M., \& Monfort, J. M. (1997). Bacterial starter cultures for meat fermentation. Food Chemistry, 59(4), 547-554. http://dx.doi. org/10.1016/S0308-8146(97)00005-8.

Hummel, A., Hertel, C., Holzapfel, W., \& Franz, C. (2007). Antibiotic resistances of starter and probiotic strains of lactic acid bacteria. Applied and Environmental Microbiology, 73(3), 730-739. http:// dx.doi.org/10.1128/AEM.02105-06. PMid:17122388.

Klayraung, S., Viernstein, H., Sirithunyalug, J., \& Okonogi, S. (2008). Probiotic properties of Lactobacilli isolated from Thai traditional food. Scientia Pharmaceutica, 76(3), 485-503. http://dx.doi.org/10.3797/ scipharm.0806-11.

Kloos, W. E., Tornabene, T. G., \& Schleifer, K. H. (1974). Isolation and characterization of micrococci from human skin, including two new species: Micrococcus lylae and Micrococcus kristinae. International Journal of Systematic Bacteriology, 24(1), 79-101. http://dx.doi. org/10.1099/00207713-24-1-79.

Laranjo, M., Potes, E. M., \& Elias, M. (2019). Role of starter cultures on the safety of fermented meat products. Frontiers in Microbiology, 10, 853. http://dx.doi.org/10.3389/fmicb.2019.00853. PMid:31133993.

Ledina, T., Mijačević, Z., Bulajić, S., \& Babić, M. (2013). Probiotic status of lactic acid bacteria. Veterinarski Jurnal Republike Srpske, 2, 176-192. (in Serbian: Probiotski status bakterija mlečne kiseline). https://doi.org/10.7251/VJRS1302176L.

Lee, C. S., Lee, S. H., \& Kim, S. H. (2020). Milk products fermented by Lactobacillus strains modulate the gut-bone axis in an ovariectomised murine model. International Journal of Dairy Technology, 73(4), 706-717.

Macedo, R. E. F., Pflanzer, O. S., \& Gomes, C. L. (2012). Probiotic meat products. In I.C. Rigobelo (Ed.), Probiotic in animals. London: IntechOpen. http://dx.doi.org/10.5772/50057.
Maijala, R., \& Eerola, S. (1993). Contaminant lactic bacteria of dry sausages produce histamine and tyramine. Meat Science, 35(3), 387-395. http://dx.doi.org/10.1016/0309-1740(93)90043-H. PMid:22061231.

Mathara, J. M., Schillinger, U., Guigas, C., Franz, C., Kutima, P. M., Mbugua, S. K., Shin, H. K., \& Holzapfel, W. H. (2008). Functional characteristics of Lactobacillus spp. from traditional Maasai fermented milk products in Kenya. International Journal of Food Microbiology, 126(1-2), 57-64. http://dx.doi.org/10.1016/j.ijfoodmicro.2008.04.027. PMid:18539351.

Mauriello, G., Casaburi, A., Blaiotta, G., \& Villani, F. (2004). Isolation and technological properties of coagulase negative staphylococci from fermented sausages of Southern Italy. Meat Science, 67(1), 149-158. http://dx.doi.org/10.1016/j.meatsci.2003.10.003. PMid:22061128.

Messens, W., Verluyten, J., Leroy, F., \& De Vuyst, L. (2003). Modelling growth and bacteriocin production by Lactobacillus curvatus LTH 1174 in response to temperature and $\mathrm{pH}$ values used for European sausage fermentation processes. International Journal of Food Microbiology, 81(1), 41-52. http://dx.doi.org/10.1016/S01681605(02)00168-X. PMid:12423917.

Nikolic, M., Terzic-Vidojevic, A., Jovcic, B., Begovic, J., Golic, N., \& Topisirovic, L. (2008). Characterization of lactic acid bacteria isolated from Bukuljac, a homemade goat's milk cheese. International Journal of Food Microbiology, 122(1-2), 162-170. http://dx.doi.org/10.1016/j. ijfoodmicro.2007.11.075. PMid:18177967.

Nowak, A., Śliżewska, K., Błasiak, J., \& Libudzisz, Z. (2014). The influence of Lactobacillus casei DN 114001 on the activity of faecal enzymes and genotoxicity of faecal water in the presence of heterocyclic aromatic amines. Anaerobe, 30, 129-136. http://dx.doi.org/10.1016/j. anaerobe.2014.09.014. PMid:25280921.

Paglarini, C. D. S., Vidal, V. A. S., Santos, M., Cruz, A. G., \& Pollonio, M. A. R. (2020). Using dynamic sensory techniques to determine drivers of liking in sodium and fat-reduced Bologna sausage containing functional emulsion gels. Food Research International, 132, 109066. http://dx.doi.org/10.1016/j.foodres.2020.109066. PMid:32331676.

Papamanoli, E., Tzanetakis, N., Litopoulou-Tzanetaki, E., \& Kotzekidou, P. (2003). Characterization of lactic acid bacteria isolated from a Greek dry-fermented sausage in respect of their technological and probiotic properties. Meat Science, 65(2), 859-867. http://dx.doi. org/10.1016/S0309-1740(02)00292-9. PMid:22063449.

Parente, E., Grieco, S., \& Crudele, M. A. (2001). Phenotypic diversity of lactic acid bacteria isolated from fermented sausages produced in Basilicata (Southern Italy). Journal of Applied Microbiology, 90(6), 943-952. http://dx.doi.org/10.1046/j.1365-2672.2001.01328.x. PMid:11412324.

Phalakornkule, Ch., \& Tanasupawat, S. (2007). Characterization of lactic acid bacteria from traditional thai fermented sausages. Journal of Culture Collections, 5, 46-57.

Radulović, Z., Petrović, T., Nedović, V., Dimitrijević, S., Mirković, N., Petrušić, M., \& Paunović, D. (2010). Characterization of autochthonous Lactobacillus paracasei strains on potential probiotic ability. Mljekarstvo, 60(2), 86-93. Retrieved from https://hrcak.srce.hr/55147

Rantsiou, K., \& Cocolin, L. (2006). New developments in the study of the microbiota of naturally fermented sausages as determined by molecular methods: a review. International Journal of Food Microbiology, 108(2), 255-267. http://dx.doi.org/10.1016/j.ijfoodmicro.2005.11.013. PMid:16481061.

Semedo-Lemsaddek, T., Carvalho, L., Tempera, C., Fernandes, H. M., Fernandes, J. M., Elias, M., Barreto, S. A., \& Fraqueza, J. M. (2016). Characterization and technological features of autochthonous coagulase-negative staphylococci as potential starters for portuguese 
dry fermented sausages. Journal of Food Science, 81(5), 197-202. http://dx.doi.org/10.1111/1750-3841.13311. PMid:27095684.

Shin, M. S., Han, S. K., Ji, A. R., Kim, K. S., \& Lee, W. K. (2008). Isolation and characterization of bacteriocin-producing bacteria from the gastrointestinal tract of broiler chickens for probiotic use. Journal of Applied Microbiology, 105(6), 2203-2212. http://dx.doi. org/10.1111/j.1365-2672.2008.03935.x. PMid:19120666.

Shinoda, Y., Sakai, Y., Ué, M., Hiraishi, A., \& Kato, N. (2000). Isolation and characterization of a new denitrifying spirillum capable of anaerobic degradation of phenol. Applied and Environmental Microbiology, 66(4), 1286-1291. http://dx.doi.org/10.1128/AEM.66.4.1286-1291.2000. PMid:10742201.

Sieladie, D. V., Zambou, N. F., Kaktcham, P. M., Cresci, A., \& Fonteh, F. (2011). Probiotic properties of lactobacilli strains isolated from raw cow milk in the. Inovative romanian. Food Biotechnology, 9, 12-28. Retrieved from https://www.researchgate.net/publication/258240131

Suskovic, J., Brkic, B., Matosic, S., \& Maric, V. (1997). Lactobacillus acidophilus M92 as potential probiotic strain. Milchwissenschaft. Milk Science International, 52, 430-435.

Šušković, J., Kos, B., Matošić, S., \& Besendorfer, V. (2000). The effect of bile salts on survival and morphology of a potential probiotic strain Lactobacillus acidophilus M92. World Journal of Microbiology \& Biotechnology, 16(7), 673-678. http://dx.doi.org/10.1023/A:1008909505651.

Tomé, E., Pereira, V. L., Lopes, C. I., Gibbs, P. A., \& Teixeira, P. C. (2008). In vitro tests of suitability of bacteriocin-producing lactic acid bacteria, as potential biopreservation cultures in vacuum-packaged cold-smoked salmon. Food Control, 19(5), 535-543. http://dx.doi. org/10.1016/j.foodcont.2007.06.004.

Työppönen, S., Petäjä, E., \& Mattila-Sandholm, T. (2003). Bioprotectives and probiotics for dry sausages. International Journal of Food Microbiology, 83(3), 233-244. http://dx.doi.org/10.1016/S01681605(02)00379-3. PMid:12745229.

Urso, R., Comi, G., \& Cocolin, L. (2006). Ecology of lactic acid bacteria in Italian fermented sausages: isolation, identification and molecular characterization. Systematic and Applied Microbiology, 29(8), 671680. http://dx.doi.org/10.1016/j.syapm.2006.01.012. PMid:16510261.

Vasilev, D., Aleksic, B., Tarbuk, A., Dimitrijevic, M., Karabasil, N., Cobanovic, N., \& Vasiljevic, N. (2015). Identification of lactic acid bacteria isolated from Serbian traditional fermented sausages Sremski and Lemeski kulen. Procedia Food Science, 5, 300-303. http://dx.doi. org/10.1016/j.profoo.2015.09.071.

Vesković Moračanin, S., Obradović, D., Velebit, B., Borović, B., \& Skrinjar, M. (2009). Antimikrobial properties of indigenous Lactobacillus sakei strain. Acta Veterinaria, 60(1), 59-66. http://dx.doi.org/10.2298/ AVB1001059V.

Vidal, V. A. S., Nachtigall, F. M., Baseggio, A., Marostica Junior, M. R., Santos, L. S., \& Rodrigues Pollonio, M. A. (2020). How does reducing sodium impact the proteolysis and texture in salted meat along 180 days of shelf life? Emirates Journal of Food and Agriculture, 32(9), 653-657. http://dx.doi.org/10.9755/ejfa.2020.v32.i9.2162.

Vlková, E., Rada, V., Popelářová, P., Trojanová, I., \& Killer, J. (2006). Antimicrobial susceptibility of bifidobacteria isolated from gastrointestinal tract of calves. Livestock Science, 105(1-3), 253-259. http://dx.doi.org/10.1016/j.livsci.2006.04.011.

Yuksekdag, Z., \& Aslim, B. (2010). Assessment of Potential Probiotic and Starter Properties of Pediococcus spp. Isolated from TurkishType Fermented Sausages (Sucuk). Journal of Microbiology and Biotechnology, 20(1), 161-168. http://dx.doi.org/10.4014/ jmb.0904.04019. PMid:20134248.

Zdolec, N., Dobranić, V., Horvatić, A., \& Vučinić, S. (2013). Selection and application of autochthonous functional starter cultures in traditional Croatian fermented sausages. International Food Research Journal, 20(1), 1-6. Retrieved from https://www.researchgate.net/ publication/234015579

Zendeboodi, F., Khorshidian, N., Mortazavian, A. M., \& Cruz, A. G. (2020). Probiotic: conceptualization from a new approach. Current Opinion in Food Science, 32, 103-123. http://dx.doi.org/10.1016/j. cofs.2020.03.009.

Žugić Petrović, T., Ilić, P., Muruzović, M., Mladenović, K., Stanisavljević, D., \& Čomić, Lj. (2019). Dry-fermented sausage as probiotic carrier food. Die Fleischwirtschaft, 99(2), 100-103.

Žugić-Petrović, T., Ilić, P., Mladenović, K., Grujović, M., Kocić-Tanackov, S., \& Čomić, Lj. (2020). Probiotic potential of autochthone microbiota from dry-cured sheep ham. Journal of Food Safety and Food Quality, 6(71), 146-151. 